\title{
Ex vivo model for the assessment of the cytotoxicity of biological material from patients with carbohydrate metabolism disturbances
}

Model ex vivo do oceny cytotoksyczności materiału biologicznego pochodzącego od pacjentów z zaburzeniami metabolizmu węglowodanów

\section{${ }^{1}$ Agnieszka Piwowar, ${ }^{1}$ Anna Rorbach-Dolata, ${ }^{2}$ Natalia Głogowska, ${ }^{3}$ Dorota Bednarska-Chabowska}

\author{
'Department of Toxicology, Faculty of Pharmacy, Wroclaw Medical University, Poland \\ ${ }^{2}$ Students' Scientific Society at the Department of Toxicology, Faculty of Pharmacy, Wroclaw Medical \\ University, Poland \\ ${ }^{3}$ Department of Angiology, Hypertension, and Diabetes, Faculty of Postgraduate Medicine, Wroclaw \\ Medical University, Poland
}

\begin{abstract}
Background: Carbohydrate metabolism disturbances have long been considered the cause of civilisation diseases, such as type 2 diabetes, obesity, or cardiovascular diseases. Currently an increasing number of theses also link impaired glucose and/or insulin metabolism to neurodegenerative diseases, calling them neurometabolic diseases.

Aim of the study was to assess the cytotoxic influence of multicompound biological material (blood serum) from people with different carbohydrate metabolism disturbances to the viability of PC12 cell line.

Material and methods: Undifferentiated PC12 cell line were incubated for 48 hours in standard conditions with the addition of human serum from individuals with diffrent (low and high) levels of hyperglycaemia (LGL and HGL) and hyperinsulinaemia (LIL and HIL). The cytotoxicity was estimated by the MTT test, and the viability percentage (SP\%) was calculated in relation to control samples (cells incubated only with RPMI).

Results: The obtained results indicate cytotoxic activity and decreased viability of the PC12 cells after 48 hours of incubation with human serum with different degrees of hyperglycaemia and insulinaemia. Cell viability increased slightly with the increase in glucose level but decreased with the increase in insulin concentration in individual groups, but without statistical significance.

Conclusions: Blood serum, as multicompound biological material, influences negatively PC12 cell line but in a variety of ways. Increasing hyperinsulinaemia has a higher cytotoxic effect on the cells than hyperglycaemia, which probably results from the fact that it is compensated by other components of biological material; however, further studies are necessary to obtain more detailed characteristics of these processes.
\end{abstract}

Key words:

cytotoxicity, hyperglycaemia, hyperinsulinaemia, biological material, PC12 cell line.

\section{Streszczenie}

Wstęp: Zaburzenia gospodarki węglowodanowej od dawna są uznawane za przyczynę występowania chorób cywilizacyjnych, takich jak cukrzyca typu 2, otyłość czy choroby sercowo-naczyniowe. Obecnie pojawia się coraz więcej tez łączących również nieprawidłowy metabolizm glukozy i/lub insuliny z chorobami neurodegeneracyjnymi, nadając im miano chorób neurometabolicznych.

Cel pracy: Ocena cytotoksycznego działania wieloskładnikowego materiału biologicznego (surowica krwi) pochodzącego od osób z różnego stopnia zaburzeniami metabolizmu węglowodanów na przeżywalność komórek linii PC12.

Materiał i metody: Niezróżnicowane komórki PC12 inkubowano przez 48 godzin w standardowych warunkach z dodatkiem surowicy ludzkiej pochodzącej od osób z różnym stopniem (niskim i wysokim) hiperglikemii (LGL i HGL) i hiperinsulinemi (LIL i HIL). Cytotoksyczność oceniono testem MTT i obliczono procent przeżywalności (SP\%) w stosunku do próby kontrolnej (komórki inkubowane jedynie z RPMI).

Wyniki: Uzyskane wyniki pokazują cytotoksyczne działanie i zmniejszoną przeżywalność komórek PC12 po 48 godzinach inkubacji z surowicą ludzką z różnego stopnia zaburzeniami glikemii i insulinemii. Przeżywalność komórek była nieco większa wraz ze zwiększeniem stężenia glukozy, natomiast spadała wraz ze zwiększeniem stężenia insuliny w poszczególnych grupach. 
Wnioski: Wieloskładnikowy materiał biologiczny, jakim jest surowica krwi pochodząca od osób z różnym stopniem zaburzeń gospodarki węglowodanowej, wpływa niekorzystnie na komórki linii PC12, ale w różny sposób. Narastająca hiperinsulinemia działa bardziej cytotoksycznie na komórki niż hiperglikemia, co prawdopodobnie wynika z tego, że jest ona kompensowana przez inne składowe materiału biologicznego, jednak dalsze badania są konieczne dla dokładnej charakterystyki tych procesów.

\section{Słowa kluczowe:}

cytotoksyczność, hiperglikemia, hiperinsulinemia, materiał biologiczny, komórki linii PC12.

\section{Introduction}

Carbohydrate metabolism abnormalities have been long considered the main cause of civilisation diseases, such as type 2 diabetes, obesity, metabolic syndrome, or cardiovascular diseases [1, 2]. Lately has become more and more common to link impaired metabolism of glucose and other carbohydrates to neurodegenerative diseases, such as Alzheimer's disease, giving them the name of neurometabolic diseases [3]. It is indicated that in people with diabetes the risk of occurrence of dementia is significantly higher [4]. It is significant due to the alarming statistical data concerning the increasing number of cases of both diabetes and neurodegenerative disorders. According to $\mathrm{WHO}$ estimates, there are over 425 million people suffering from diabetes in the world, and this number has doubled within the last 30 years. Furthermore, 42 million individuals in the world suffer from dementia, and this number is increasing by 10 million each year [2]. The extent of this problem prompted scientists to try to explain the pathomechanisms responsible for the increased occurrence of Alzheimer's disease in the population of people suffering from diabetes.

Theories that link neurodegenerative diseases to disturbances in carbohydrate metabolism in the central nervous system (CNS) seem promising because glucose is the main energy source for the brain and its impaired supply conditions chronic pathological states in neuron function [5]. Impaired carbohydrate metabolism is related to cognitive function disorders of both vascular and neurodegenerative origin. Increased glucose concentration in systemic circulation translates into its increased concentration in cerebral circulation when the storing capacity of astrocytes is exceeded $[6,7]$. The glycation process increases as well, both in the neurons and in the cells of cerebral circulation, which additionally induces disorders in the CNS [8]. For this reason, hyperglycaemia is considered to be a significant element in pathogenesis of neurodegenerative diseases [9]. Among numerous micro- and macroangiopathic vascular complications of diabetes the disturbances in the brain are especially difficult to detect. In hyperglycaemia changes take place in the structure and physiological function of the neurons, and disturbances in neurotransmission, known as diabetic encephalopathies, occur [10]. The role of insulin as a regulating factor, excreted in the state of hyperglycaemia, which passes through the blood-brain barrier, is an important aspect in neuroendocrine disorders. Due to insulin receptors in the CNS, its activity is twofold: it acts as a peptide hormone and as a neurotransmitter for the neurons [11]. Literature data indicate that peripheral hyperinsulinaemia directly influences the development of insulin resistance in the brain and, consequently, neuronal disturbances, and predisposes also to development of neurodegenerative disorders $[9,12,13]$.

States of hyperglycaemia in combination with insulin resistance and hyperinsulinaemia, observed in individuals with impaired carbohydrate metabolism, are an important factor in further development of biochemical disturbances and the pathogenesis of clinical complications. They also predispose to the development of many neurodegenerative diseases, which has become an object of interest among many scientists $[3,12,14]$. Most of the literature to date concern the influence of individual, chemically pure substances (for example, glucose, insulin, glutathione solutions), which are conducted in vivo on animal models or in vitro on different cell lines $[15,16]$. However, there are no studies on models conducted in vitro that would analyse changes induced by multicompound biological material (for example blood serum) from people with different degrees of disturbances in carbohydrate metabolism. The PC12 cell line is among the most commonly used in in vitro studies. Thanks to the analogy in morphology and in the function of sympathetic neurons, it is used in many studies within the scope of broadly defined neuroendocrinology. It is often used for initial assessment of cytotoxic activity of potentially harmful agents, both without differentiating the cells with neuron growth factor (nerve growth factor, NGF) $[17,18]$ and after their differentiation with the NFG in line of cells similar to the neurons of the sympathetic nervous system, which enable the estimation of neurotoxic activity $[15,19]$.

The aim of the study was assessment of the influence of multicompound biological material (blood serum) from patients with disturbances in carbohydrate metabolism, reflected by different levels of hyperglycaemia and hyperinsulinaemia, on the viability of PC12 cell line. Changes in metabolic activity of cells after incubation with biological material were assessed using the MTT test and related to the percentage of viability (SP\%) of the cells not exposed to any exogenous agents.

\section{Material and methods}

In this study blood serum and the PC12 cell line were used to conduct the experiments. The blood was from patients of the Clinic of Angiology, Diabetology, and Hypertension of Wroclaw Medical University, who were admitted to the hospital due to non-normalised glycaemia or clinical disorders resulting from it. In the examined individuals, other comorbidities and inflammatory conditions were excluded. All patients gave consent 
to participate in the study and the use of biological material was approved by the Bioethical Committee of the Medical University in Wroclaw (no. KB-629/2016). The whole blood from 48 individuals (aged 27 to 83 years), 33 women and 15 men, was collected into sterile Vacutainer tubes, and then it was centrifuged at 2000 rpm for 15 minutes; the obtained serum was pipetted in sterile conditions into Eppendorf test tubes and stored at $-85^{\circ} \mathrm{C}$ until conducting further in vitro studies. The PC12 cell line was grown and passaged in standard conditions according to the applied procedure that was described in our previous studies [20]. In order to conduct the planned studies, the cells in a stable amount $\left(2-4 \times 10^{6}\right.$ of living cells/ml RPMI medium) were incubated with biological material - blood serum mixed with fresh RPMI medium at a constant volume (v/v 20\%).

For the purposes of the constructed research model, concentrations of glucose and insulin were measured in each sample, using the GOD-POD method (Glucose GOD Insert, Labtest, Brasil) and the immunological and enzymatic methods (DRG Insulin ELISA Kits, DRG International, USA), respectively. Any patients were treated with insulin, so only level of exogenous insulin was determined. The average glucose and insulin concentrations measured in all biological material samples were equal to, respectively: $143 \mathrm{mg} / \mathrm{dl}$ and $35.8 \mu \mathrm{lU} / \mathrm{ml}$. On the basis of the obtained results, 20 samples of biological material with different glucose and insulin concentrations were selected for further analysis; the samples were categorised into four groups (five samples each). There were two groups with leading disturbances of glucose concentration: below and above $200 \mathrm{mg} / \mathrm{dl}$, respectively, reflecting the glucose concentration applied to diagnose diabetes in a so-called random blood sample, in accordance with the guidelines of the Polish Diabetes Association [21], and two groups with leading disturbances of insulin concentrations: below and over $25 \mu \mathrm{lU} / \mathrm{ml}$, respectively, which reflects the insulin concentration applied to hyperinsulinaemia diagnosis, in accordance with the Laboratory Reference Range and our prior research $[19,20]$. These groups were marked, respectively, as: LGL (low glucose level $<200 \mathrm{mg} / \mathrm{dl}$ ) and HGL (high glucose level $\geq 200 \mathrm{mg} / \mathrm{dl}$ ), as well as LIL (low insulin level $<25 \mu \mathrm{lU} / \mathrm{ml}$ ) and $\mathrm{HIL}$ (high insulin level $\geq 25 \mu \mathrm{lU} / \mathrm{ml}$ ).

All operations related to the PC12 cell line incubation with biological material were carried out in sterile conditions in a laminar chamber with a HEPA filter (Bioair Sefamate 12 CYTO) using sterile, single-use laboratory equipment. The incubation procedure included the following stages: $20 \mu \mathrm{l}$ of PC12 cell suspension in RPMI 1640 medium were added to each well of a 96-well plate; the plates were then incubated for 24 hours at $37^{\circ} \mathrm{C}$ and in an atmosphere containing $5 \% \mathrm{CO}_{2}$ in a Panasonic MCO-170AIC incubator in order to attach the cells to the well bottoms of the experimental plate. Then the culture medium was pipetted out of each well and replaced with a $200 \mu \mathrm{l}$ mixture of serum and fresh medium ( $v / v 20 \%)$; the cells were then incubated for 48 hours in the same conditions as before. The test was repeated three times for each sample of the biological material. After the end of the incubation time the MTT (methylthiazolyldiphenyl-tetrazolium bromide) test was conducted for all tested samples according to a widely described procedure that was used in our previous studies [20] to assess the cytotoxic effect of biological material. The viability of the PC12 cells, resulting from the incubation with biological material, was assessed by calculating the viability percentage of the cells (SP\%) that provided information on the number of cells still showing biological activity. The results were referred to the control group of the PC12 cells, marked as K0, where the cells were incubated in a culture medium only, without an addition of serum; the activity of the cells was assumed at the level of $100 \%$.

The statistical analysis of the obtained results was conducted using Statistica PL 13 software. The results were presented as mean values with standard deviation. The normality of distribution was checked by the Lilliefors and the KolmogorovSmirnov tests. Student's t-test was used to estimate the difference between the examined groups. The p-values below 0.05 were considered as statistically significant.

\section{Results}

The distribution of the viability percentage (SP\%) of the PC12 cells line after 48 hours of incubation with serum of patients with different degree disturbances of glycaemia and insulinaemia is presented in Figures 1 and 2, respectively. As we can observe, all the PC12 cells showed lower viability after being exposed to these serum samples in comparison to the control sample, regardless of the applied combination of these parameters (from $73.01 \%$ to $55.50 \%$ ).

Figure 1 presents an averaged viability percentage of the PC12 cell line that was incubated with serum categorised into two groups, according to glucose concentration (LGL and $H G L)$, as a leading disturbance, and adequately low and high insulin concentration (LIL and HIL) along with reference to the control sample (KO). The lowest level of viability was observed in cells incubated with the LGL and HIL serum, and it was equal

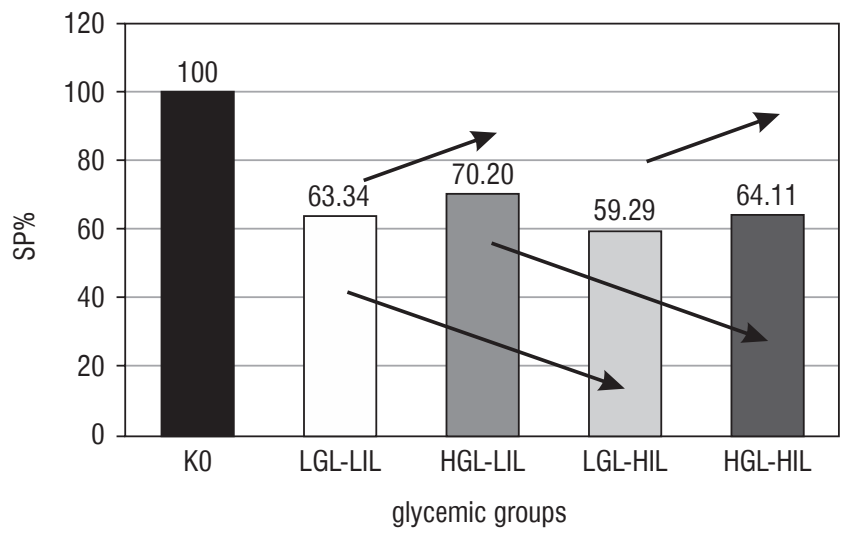

Figure 1. The SP\% of the PC12 line cells after 48 hours of incubation with serum of patients classified according to different glucose concentration, as leading disturbance, in reference to control sample (KO) 


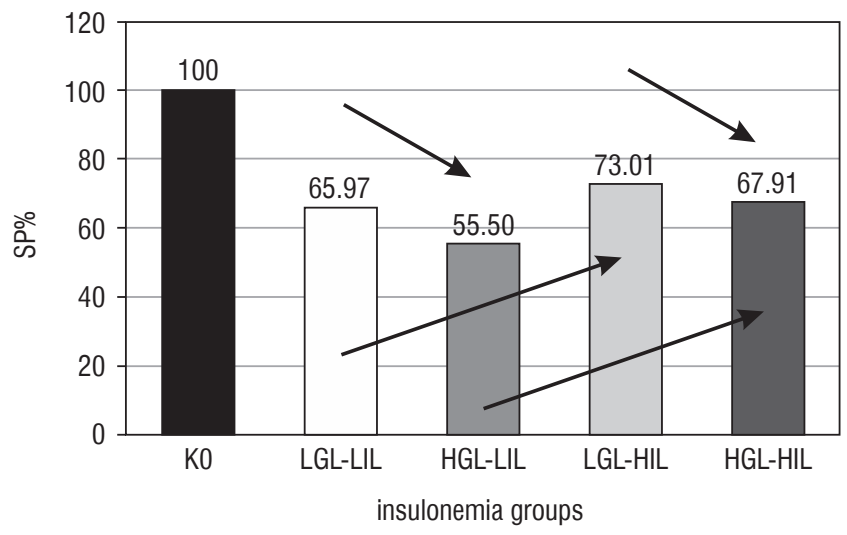

Figure 2. The SP\% of the PC12 line cells after 48 hours of incubation with serum of patients classified according to different ranges of insulin concentrations, as leading disturbance, in reference to the control sample $(\mathrm{KO})$

to $59.29 \%$. The highest SP\% (70.20\%) was observed in the cells incubated with serum with high glucose concentration and proper insulinaemia (HGL and LIL). The viability of the PC12 cell line increased along with the increase of glucose concentration in serum with the same, low level of insulin concentration (from 63.34\% to 70.20\%). A similar tendency was observed in the cells incubated with high insulin concentration (growth from $59.29 \%$ to $64.11 \%$ ). On the other hand, the analysis of the changes of SP\% in groups with low and high glucose concentration, in relation to low and high insulin concentration (LIL and HIL), showed a downward trend (from $63.34 \%$ to $59.29 \%$ and from $70.20 \%$ to $64.11 \%$, respectively). Statistically significant differences between the studied groups were not observed.

Figure 2 shows the averaged SP\% levels of the PC12 cells line incubated with serum categorised into two groups depending on the insulin concentration levels (LIL and HIL), as a leading disturbance, and, respectively, low and high glucose concentration levels ( $L G L$ and $H G L)$, along with reference to the control (KO). As described above, the lowest viability was observed for the cells incubated with the serum with HIL and LGL (55.50\%), and the highest was observed for the cells incubated with serum of low insulin levels and high glucose concentration $(73.01 \%)$. The viability of the PC12 cell line dropped with the increase in insulin concentration in serum with the same low glucose concentration (from $65.97 \%$ to $55.50 \%$ ). A similar trend was observed for the cells incubated with high glucose concentration (decrease from $73.01 \%$ to $67.91 \%$ ). On the other hand, the analysis of the SP\% in groups with low and high insulin concentration, in relation to low and high glucose level ( $\mathrm{GL}$ and HGL), showed an upward trend (from 65.97\% to $73.01 \%$ and from $55.50 \%$ to $67.91 \%$, respectively). Despite the fact that the highest SP\% change was found between the samples in groups with high insulin level and different glucose concentrations (by $12.41 \%$ ), no statistically significant differences were found between the analysed groups.

\section{Discussion}

Conducting in vitro research on model systems, namely cell lines, enables an initial, non-invasive assessment of the influence of different endo- and/or exogenous factors, and it provides significant information on the effects of their action, possible metabolic pathways, and mechanisms of action, which can be, to a certain extent, referenced to the in vitro conditions [15, 19, 24]. Regarding the indicated correlation of growing incidence of neurodegenerative diseases in people with diabetes, conducting research in different aspects of chronic disturbances in carbohydrate metabolism assessment is still actual, and experiments using cell lines are widely applied; however, they do not always reflect its concentration in in vivo conditions. Literature data $[17,18,25]$ and the results of our initial research indicate a significant role of high glucose and/or insulin concentrations in cytotoxic damage to model cell lines and a decrease in their viability. However, there is little research that would assess the results of exposure to multicompound biological material, which is human serum, from patients with different degrees of disturbances in carbohydrate metabolism (reflected by glycaemia and insulinaemia disturbances) in in vivo conditions. That became the subject of our research on the developed ex vivo assessment model for cytotoxic activity and influence on the viability of the PC12 cell line. In order to relate the obtained results to the data from the references for our initial research, a pattern of the experiments conducted without differentiation of the PC12 cells with the NFG factor was chosen; the same was applied by other scientists $[17,18]$.

The results of the research showed cytotoxic activity of multicompound biological material, which is reflected by the decrease in the PC12 cell viability as a result of its incubation with serum classified into different groups according to the blood glucose level (to LGL and HGL groups), as a leading disturbance, and the insulinaemia (the LIL and HIL groups), as a leading disturbance. The lowest viability was observed for the PC12 cell line incubated with the serum from patients of the HIL and LGL group (55.50\%) and the highest - from the LIL and HGL group and (73.01\%). We observed an increase trend in SP\% along with the increase of blood glucose level. Observations concerning the decrease in PC12 cell line viability resulting from exposure to glucose solutions were also made by Sharifi et al. [17], who, in the applied in vitro research model, also used the PC12 cell line. However, the authors focused on the phenomenon of diabetic neuropathy and the role of apoptosis induced by Bax/BcL2 protein pathway. The conducted experiments did not reflect physiological concentrations of glucose present in the nervous tissue that are characteristic to various states of glycaemia disturbances. It was shown that in the case of direct exposure of the PC12 cells to glucose in a concentration equal to $13.5 \mathrm{mg} / \mathrm{ml}$ (three times higher than the physiological level) the viability of cells in the MTT test decreased along with elongation of the incubation time (24, 48, 72, and 96 hours) in comparison to the control sample - from almost $85 \%$ to almost $60 \%$. Moreover, it was 
shown that apoptosis plays an important role, possibly via the mitochondrial pathway, through higher expression of Bax proapoptotic protein. Also, the research of Chen et al. [18] on the influence of hyperglycaemia in different ranges of glucose concentration (50-150 mM), and in different times (24-72 hours), on the metabolic activity of the PC12 cell line confirmed the above-cited thesis stating that cell mortality increases along with the incubation time and glucose concentrations applied.

The above-cited research results are different from the results obtained in our study in which we observed an increase in viability of the PC12 cells incubated with biological material with higher glucose concentrations ( $\geq 200 \mathrm{mg} / \mathrm{dl}$ ) matching hyperglycaemia in the so-called random blood sample, appropriate for diagnosing diabetes. These differences may result from using different (significantly higher) glucose concentrations and different conditions of the PC12 cell line exposure to cytotoxic factors - they were exposed to pure solutions of chemical substances. The cells incubated with patients' serum were indirectly exposed to glucose and/or insulin concentrations because, apart from these factors, other biochemical components are also present in biological material (including cholesterol and its fractions - HDL and LDL, gamma-globulins, antibodies, hormones, growth factors, interleukins, etc.). One can search for the presence and the influence of protective factors removing or reducing cytotoxic activity of glucose toward examined cells in multicompound composition of biological material; this could be an interesting facet for further research.

The ex vivo constructed model used in this paper allowed us to observe the complexity and not obvious action of biological material. The conducted research could be continued in the future by attempting to juxtapose the morbidity percentage of nerve-like cells, differentiated with the NFG factor toward neuronal cells, induced by various levels of hyperglycaemia with different biochemical parameters, such as cholesterol concentration and its fractions (HDL, LDL), globulins, adipokines, cytokines, and other factors present in blood serum. The number of research projects focusing on finding reliable information on biological material influence (mainly blood serum) on different cell lines is growing. In the conducted research the synergistic influence of different biological material components on cells of different lines is analysed. It allows the researchers to compare and partially refer the changes induced in in vivo and in vitro conditions. In this case, our study fits the current research trends. In an experiment conducted by Nooteboom et al. [26] the influence of human plasma obtained from lipopolysaccharide (LPS) derived from $E$. coli (endotoxin) stimulated whole blood on modulation of endothelial monolayer HUVEC (human umbilical vein endothelial cells) permeability was analysed in order to examine the mechanisms responsible for systemic oedema and septic shock. It was proven that these factors increase the permeability of the HUVEC cells, which may contribute to finding an explanation of the mechanisms responsible for inflammatory reactions and oedemas. OleśkowskaFlorek et al. [27] also compared the results of the HUVEC cell line incubation with blood serum of patients before and during dialysis. They observed an increase in proliferation of cells exposed to the action of blood serum, which confirmed that removing toxins during dialysis decreases the cytotoxicity of blood plasma toward endothelial cells. Aghajanova et al. [28] used in their research mesenchymal stem cells of endometrium (eMSC), mesenchymal stem cells from bone marrow (BMSCs), and fibroblasts from human endometrium (eSF), which were exposed to plasma enriched with platelets and growth factors. The authors observed an increase in proliferation in all types of endometrium cells. Additionally, after three or seven days, depending on the culture growth rate, cell chemotaxis and wound healing processes were also improved.

The above-mentioned research, which analysed the influence of biological material on cell lines, seems to be more adequate in comparison to the research carried out during our work, because they were conducted in similar culture conditions; the cells were incubated with compound human biological material, namely blood plasma/serum, but the parameters of carbohydrate metabolism were not assessed. The results obtained by us are the first step to further development of research on the PC12 cell line differentiated by the NFG factor, or human neural stem cell line from umbilical blood (HUCB-NSC); the results indicate the necessity to explain the mechanisms responsible for changes in viability levels of the PC12 cells $[20,29]$. High glucose concentrations in the examined serum do not influence cells as negatively as does direct exposure of the PC12 line to high concentrations of chemically pure solutions of glucose.

We observed a different trend in changes of the PC12 cell line viability in relation to incubation of cells with serum from patients with different degree of insulinaemia; we found a decrease in SP\% that occurred along with an increase in insulinaemia, where it was lower for the samples with the highest hormone concentration ( $\geq 25 \mu \mathrm{lU} / \mathrm{ml}$ ), which corresponds with hyperinsulinaemia conditions that have been accepted by scientific societies as characteristic for this state and that are used to diagnose it. The observations made coincide with those from our earlier studies that directly assessed the cytotoxicity of chemically pure insulin solutions toward the PC12 line cells, with concentrations adjusted on the basis of hormone concentration present in the states of normal-, moderate-, and high-level insulinaemia in in vivo conditions. The existing trend of hyperinsulinaemia-induced changes, where we used biological material from patients with disturbed carbohydrate metabolism, may suggest that stronger cytotoxic activity of hyperinsulinaemia, which causes a decrease in the PC12 cell line viability, is not compensated by other components of biological material as it may be in case of lower influence of hyperglycaemia states. The obtained results may indicate a weaker protective effect of insulin in ex vivo conditions on the PC12 cells line, which does not coincide with the protective function of insulin in the CNS in in vivo conditions. This problem seems to be interesting and requires further research because in the scientific literature only a few data concerning this facet are present. Song et al. [12], in studies examining the neuroprotective influence of insulin on apoptosis of PC12 cell line induced by $\mathrm{H}_{2} \mathrm{O}_{2}$, proved a positive result of incubating these with 
directly added insulin in growing concentrations (25, 50, 100, and $200 \mathrm{mmol} / \mathrm{L}$ ) and increased viability of cells despite the activity of a pro-apoptotic agent. Nampoothiri et al. [25] proved the protective effect of insulin in the conditions of toxic activity of glutamate, using cells from the human neuroblastoma line (SH-SY5Y). They incubated the SH-SY5Y cell line with human recombinant insulin in a configuration with glutamate and on its own. The authors not only did not observe negative activity of the hormone, but also found that during joint exposure of the cells to insulin and glutamate insulin showed its protective effect. In reference to our own research, the differences may result from the fact that insulin concentrations present in serum and other component factors of biological material may significantly change the metabolic activity of the PC12 cell line and give somewhat different results than chemically pure solutions.

Recently, the promising role of in vitro model research in $3 \mathrm{D}$ cultures that enable the scientists to examine more deeply the adhesion of cells, their distribution, growth, morphology, proliferation, differentiation, or gene and protein expression as a result of action of the tested agents has been indicated. The 3D cultures are widely applied in different scientific fields such as pharmacology, neurobiology, oncology, or in research related to cell differentiation [30]. It is shown that they will also be an excellent research model for the assessment of disorders in the CNS, which, in compilation with activity of multicompound biological material, namely serum from individuals with different degrees of disturbance in carbohydrate metabolism, will constitute an interesting research model for learning about their interactions and for the assessment of

\section{References}

1. Scherer PE, Hill JA. Obesity, Diabetes, and Cardiovascular Diseases: A Compendium. Circ Res 2016; 118: 1703-1705. doi: 10.1161/ CIRCRESAHA.116.308999

2. Światowa Organizacja Zdrowia: WHO oglasza nowe dane o cukrzycy na świecie Światowy raport na temat cukrzycy przedstawia sytuację i działania podejmowane, wersja aktualna 2016. Available at: http://apps.who.int/diabetes/country-profiles/pol_en.pdf?ua=1 (accessed 12 December 2017).

3. Kang S, Lee Y, Lee J. Metabolism-centric overview of the pathogenesis of Alzheimer's disease. Yonsei Med J 2017; 58: 479-488. doi: 10.3349/ymj.2017.58.3.479

4. Chami B, Steel AJ, De La Monte SM, Sutherland GT. The rise and fall of insulin signaling in Alzheimer's disease. Metab Brain Dis 2016; 31: 497-515. doi: 10.1007/s11011-016-9806-1

5. De La Monte S. Alzheimer's disease is type 3 diabetes-evidence reviewed. J Diabetes Sci Technol 2008; 22: 1101-1113. doi: 10.1177/ 193229680800200619

6. Malik R. Pathology of human diabetic neuropathy. Handb Clin Neurol 2014; 126: 249-259.

7. Roh E, Song DK, Kim MS. Emerging role of the brain in the homeostatic regulation of energy and glucose metabolism. Exp Mol Med 2016; 48: e216. doi: 10.1038/emm.2016.4 their protective and pathogenic activity in the development of neurodegenerative diseases.

\section{Conclusions}

The incubation of the PC12 cell line with serum from patients with different degrees of glycaemia and insulinaemia disorders significantly influences the viability of model line cells, but in an ambiguous way, and it is related to glucose and insulin concentration in samples. SP\% varies between $55.29 \%$ and $73.01 \%$ in comparison with a control sample, not exposed to the action of biological material. Serum from patients with hyperinsulinaemia showed higher cytotoxicity toward the PC12 line cells than serum with confirmed hyperglycaemia, which suggests activity of different agents that could compensate the negative impact of high glucose concentrations in biological material; however, further research aimed at explaining the mechanisms responsible for these effects is necessary.

\section{Acknowledgements}

This work was supported by a Wroclaw Medical University grant for young scientists (number STM.D150.17.063). The authors wouod like to thank the Diagnostic Laboratory for Teaching and Research, Faculty of Pharmacy with Division of Laboratory Diagnostics, Wroclaw Medical University, for help with the laboratory measurements of glucose and insulin concentration.

8. Hussain M, Bork K, Gnanapragassam VS, et al. Novel insights in the dysfunction of human blood-brain barrier after glycation. Mech Ageing Dev 2016; 155: 48-54. doi: 10.1016/j.mad.2016.03.004

9. Chen Z, Zhong C. Decoding Alzheimer's disease from perturbed cerebral glucose metabolism: Implications for diagnostic and therapeutic strategies. Prog Neurobiol 2013; 108: 21-43. doi: 10.1016/j. pneurobio.2013.06.004

10. Akintola AA, van Heemst D. Insulin, aging, and the brain: mechanisms and implications. Front Endocrinol 2015; 6: 13. doi: 10.3389/ fendo.2015.00013

11. Gray SM, Meijer RI, Barrett EJ. Insulin regulates brain function, but how does it get there? Diabetes 2014; 63: 3992-3997. doi: 10.2337/ db14-0340

12. Song $Y$, Ding W, Bei Y. Insulin is a potential antioxidant for diabetesassociated cognitive decline via regulating Nrf2 dependent antioxidant enzymes. Biomed Pharmacother 2018; 104: 474-484. doi: 10.1016/j.biopha.2018.04.097

13. Arnold SE, Arvanitakis Z, Macauley-Rambach SL, et al. Brain insulin resistance in type 2 diabetes and Alzheimer disease: concepts and conundrums. Nat Rev Neurol 2018; 14: 168-181. doi: 10.1038/ nrneurol.2017.185

14. de Nazareth AM. Type 2 diabetes mellitus in the pathophysiology of Alzheimer's disease. Dement Neuropsychol 2017; 11: 105-113. doi: 10.1590/1980-57642016dn11-020002 
15. WesterinkR, Ewing A. The PC12 cell as model for neurosecretion. Acta Physiol 2008; 192: 273-285. doi: 10.1111/j.1748-1716.2007.01805.x

16. Žourek M, Kyselová P, Čechurová D, Rušavý Z. Acute glycemic changes in brain and subcutaneous tissue measured by continuous glucose monitoring system in hereditary hypertriglyceridemic rat. Physiol Res 2018; 67: 127-131. doi: 10.33549/physiolres.933620

17. Sharifi A, Mousavi S, Farhadi M, Larijani B. Study of High GlucoseInduced Apoptosis in PC12 Cells: Role of Bax Protein. J Pharmacol Sci 2007; 104: 258-262.

18. Chen M, Zheng H, Wei T. High glucose-induced PC12 cell death by increasing glutamate production and decreasing methyl group metabolism. Biomed Res Int 2016; 2016: 4125731. doi: 10.1155/2016/4125731.

19. Grau C, Greene L. Use of PC12 Cells and Rat Superior Cervical Ganglion Sympathetic Neurons as Models for Neuroprotective Assays Relevant to Parkinson's Disease. Methods Mol Biol 2012; 846 : 201-211. doi: 10.1007/978-1-61779-536-7_18

20. Rorbach-Dolata A, Piwowar A. Adverse effect of the disturbances of glycemia and insulimemia on model PC12 cells - Preliminary report. Pediatr Endocrinol Diabetes Metab 2017; 3: 174-180. doi: 10.18544/PEDM-23.04.0090

21. Polskie Towarzystwo Diabetologiczne: Zalecenia kliniczne dotyczące postępowania u chorych na cukrzycę. Diabetol Klin 2017; Supl A: $1-81$

22. Laboratory Reference Range. Available at: https://www.mayomedicallaboratories.com/ (accessed 24 April 2018).

23. Płaczkowska S, Pawlik-Sobecka L, Kokot I, Piwowar A. Analiza czestości występowania insulinooporności u osób młodych w oparciu o wybrane kryteria diagnostyczne - badanie wstępne. Incidence of insulin resistance according to specified diagnostic criteria - a preliminary report. Hygeia Public Health 2014; 49: 851-856.

24. Resource Sharing in Biomedical Research. The American Type Culture Collection. Available at: https://www.ncbi.nlm.nih.gov/books/ NBK209072/ (date of access 30.12.2018).

25. Nampoothiri M, Reddy N, John J, et al. Insulin blocks glutamateinduced neurotoxicity in differentiated SH-SY5Y neuronal cells. Behav Neurol 2014; 2014: 674164. doi: 10.1155/2014/674164

26. Nooteboom A, Bleichrodt R, Hendriks T. Modulation of endothelial monolayer permeability induced by plasma obtained from lipopolysaccharide-stimulated whole blood. Clin Exp Immunol 2006; 144: 362-369. doi: 10.1111/j.1365-2249.2006.03074.x

27. Oleśkowska-Florek W, Połubinska A, Baum E, et al. Hemodialysis-induced changes in the blood composition affect function of the endothelium. Hemodial Int 2014; 18: 650-656. doi: 10.1111/ hdi. 12148

28. Aghajanova L, Houshdaran S, Balayan S, et al. In vitro evidence that platelet-rich plasma stimulates cellular processes involved in endometrial regeneration. J Assist Reprod Gene 2018; 35: 757770. doi: 10.1007/s10815-018-1130-8

29. Bużańska L, Neural stem cells from human cord blood - immunocytochemical, physiological and molecular analysis. Post Biol Kom 2006; 33: 667-681.

30. Słońska A, Cymerys J. Application of three-dimensional neuronal cell cultures in the studies of mechanisms of neurodegenerative diseases. Postepy Hig Med Dosw 2017; 71: 510-519. 